\title{
The Role of Tourism Activities in Alleviating the Management Cost of Puri Agung Kerambitan, Tabanan
}

\author{
Putu Lirishati Soethama ${ }^{1}$, I Gusti Agung Istri Aryani ${ }^{2}$ \\ ${ }^{1.2}$ English Literature, Faculty of Arts \\ Udayana University \\ Bukit Jimbaran, Bali, Indonesia \\ lirishati_soethama@unud.ac.id
}

\begin{abstract}
Puri Agung Kerambitan is the forerunner of pekraman village Kerambitan, Tabanan, Bali. Its vast territory covers 19 villages from Kerambitan in the south to Batuaji in the north of the palace. It is founded in 1650 as a fragment of the Kingdom of Tabanan, began to open its access to tourism in 1980, during the reign of Late A A. Ngurah Anom Mayun. Puri Agung offers several activities such as Puri Wedding, Puri Day and Puri Night Dinner for more than three decades. All of these activities involve the palace residents and villagers surrounding it. Arts attraction such as Tabuh Okokan and Tektekan Calonarang, distinctive and authentic of Kerambitan art; until the procedure of making offerings and traditional Balinese cake are displayed. The number of foreign and domestic tourists who visit the palace is certainly has a big impact on the grand cost of the palace management cost. The income and the expenses of the palace within 2016 was obtained by using a quantitative method. Interviews with the management and residents of Puri Agung Kerambitan were conducted for the validity and supporting the research data. The data and problem were analyzed using the qualitative descriptive method. This paper gives an overview and simple description of Puri Agung Kerambitan's income from its tourism activity and the expenses required for managing it. These expenses can be sorted out in physical, such as palace maintenance and staff salaries; as well as non-physical, such as ceremonial financing. The good management of tourism activities could alleviate the grand maintenance cost of the palace.
\end{abstract}

Keywords: Puri Agung Kerambitan, tourism palace, management cost

\section{INTRODUCTION}

The development of tourism in Bali has a great effect on the life of the Balinese, especially concerning the economic growth of the population. As a tourist destination, of course, Bali has many interesting tourist objects, cultural creations have high artistic value, customs, unique traditions as well as the hospitality of the local people have a major role in welcoming tourists to visit this small island. A variety of activity packages are offered, from adventure recreation, nautical recreation to the cultural tourism of learning history around the castles. Community-based tourism, communities engaged in tourism, performing arts performances, and various types of art have been ingrained in the Balinese. Tourism offers breaks, culture, escapades, adventures, and other new and different experiences. Many places in Bali, depending on the tourism industry as a source of taxes and their income. Law no. 10/2009 on Tourism stated that tourism is a variety of activities supported by various facilities and services provided by the community, businessmen, the Government, and local government.
1930 is a milestone in the development of tourism in Bali, with the establishment of Inna Bali Hotel, a colonialstyle architectural building to accommodate the increasing tourists coming at that time. World War II in 1942-1945 had an impact in pausing tourist arrivals to Bali, but the next decade, tourist dwellings growing very rapidly. Sanur, Kuta, Ubud, flooded with tourists up until now Bali has 35,000 residential tours. The number of tourists attracted to come to Bali because of its cultural uniqueness made local Government developed tourism industry based on cultural tourism policy. This policy is outlined in Local Regulation No. 3 of 1974, which was revised into Local Regulation No. 3 of 1991 on Cultural Tourism, which states that every tourism industrialization of this region must be based on Balinese culture. It is what fosters the idea and creativity of the Puri Agung Kerambitan leader in Bali to make his palace as part of the tourism culture in Bali.

Puri in Bali is a place of residence who hold the government. The building is generally located in kangin kaja at the corner of the grand T Junction, in the center of the village and is a place to store various wealth or cultural heritage that is often used as a tourist attraction by the area. 
As performed by Puri Agung Kerambitan, Tabanan, which developed its heritage as a tourist attraction because they understand that tourists are very interested to come to the royal palace/castle to see the local culture of the original people.

Puri Agung Kerambitan is the forerunner of Kerekitan pekraman village, Tabanan, Bali. Its vast territory includes 19 villages from Kerambitan and Kelating in the south and west to Serongga and Batuaji in the east and north of the royal city. This area is well known for its rice fields and irrigation systems, as well as community cooperation, democracy as well as obedience to religious norms. The kingdom, founded in 1650 as a fragment of the Kingdom of Tabanan, began to open its access to tourism in 1980, during the reign of Alm. A A. Ngurah Anom Mayun. More than three decades that Puri Agung makes themselves closer to the community through tourism activities and these activities are managed entirely by the family of the palace.

In the past the people who worked on the land owned by the palace, they also took care of all the maintenance of the palace. Along with modern life, they choose self-supporting activities to support themselves and their families. They are no longer depend only on the palace. Puri Agung kerambitan required the energy and expenses to take care and to manage their palace, began following their way into tourism. The palace manages itself for tourism activities; they get income from this tour. One of these ways is Puri Tours, not only as a tourist spot but also as accommodation such as Ubud castle and Puri Pemecutan.

The idea of opening the palace for tourism triggered by Late A A. Ngurah Anom Mayun and packed in some form of activities such as Puri Wedding, Puri Day and Puri Night Dinner. All these activities involve the palace's residents and villagers surrounding the palace. They display a variety of art attractions such as Tabuh Okokan and Tektekan Calonarang, distinctive and authentic Kerambitan art; until the procedure of making traditional offerings and jajajan Bali. The number of foreign and domestic tourists who visit the castle certainly has a big impact on the management cost of the castle which is never little.

In this research on the Role of Tourism Activities Alleviating the Management Cost of Puri Agung Kerambitan, Tabanan, we bring several issues to be discussed, such as (1) What is Puri Agung Kerambitan income from tourism activity? (2) What is the expense of physical and nonphysical physical cost of Puri Agung Kerambitan? (3) Can the income from this tourism activity help alleviate the management cost at Puri Agung Kerambitan?

The purpose of this research is to know the role of tourism activity in alleviating the management cost of Puri Agung Kerambitan. Can the income from such tourism activities help the palace's residents providing good management for Puri Agung Kerambitan. Considering that the cost incurred by the residents has never been a little for the sake of maintenance cost. The study also has a specific purpose to provide further advice to the residents of Puri Agung Kerambitan to further streamlining their tourism activities in Puri Agung, which can assist them in providing the best income for their cultural activities and Puri maintenance.

The research of Role of Tourism Activities in Alleviating the Management Cost of Puri Agung Kerambitan has significant benefits to tourism of Puri Agung Kerambitan in particular and tourism of Puri in Bali in general. There has never been a scholar before doing similar research in Puri Agung Kerambitan. So this research can provide comprehensive information about the success of tourism activities held in Puri Agung within one year, regarding income earned which is channeled to the management cost of the palace. The sample of income and expenses are taken from January 2016 to December 2016.

\section{RESEARCH METHOD}

A population is a group of people, objects or things that are the source of sampling, a set that meets certain requirements related to research problems. The population was taken based on written data of Puri Agung Kerambitan income from tourism activities which is divided into three major activities. The first, Puri Agung Kerambitan has Puri Wedding tourism attractions divided into three (3) levels namely Puri Wedding Alit, Puri Wedding Madya and Puri Wedding Agung with some activities such as Balinese bridal decoration, Baleganjur percussion, Okokan percussion, Pendet dance, Mask dance, Sekehe Kendang Mungkung dance. The second, tourism activity is packed in the theme of Puri Day which organized in the tourists spend time from morning to evening. Puri Day contains short learning activities on Balinese dance, Joged Bumbung dance attractions, traditional Balinese jajanan making lessons, egg painting, kite making and short historical introductions to the palace. The third big event is packed in the form of Puri Dinner that invites tourists to enjoy dinner while watching some Balinese dance performances.

The population was also taken by written data from the Puri Agung Kerambitan expenditure for the management of Puri regarding physical and non-physical. Physical aspects include the cost of environmental treatments in this case crops and buildings, spending on the treatment of the castle, the cost of electricity, water and the salary costs of the palace's employees. While concerning non-physical expenses cost of the castle includes daily, weekly, monthly ceremony and big ceremony or ceremony every seven months.

Seeing the grand amount of the population, it is necessary to have a sample. The sample was taken by purposive sampling technique, that is by choosing the part of the population that has been known before. The sample used is Puri Agung Kerambitan's revenue from these three major tourism activities in 2016 and expenditures for physical and non-physical maintenance costs of Puri Agung Kerambitan in 2016 as well.

After determining the population and sample as described above, the next activity is to collect and conduct 
data selection. In this phase discussed data collection methods, data analysis methods, and methods of presenting the results of data analysis.

To meet the need for complete and reliable data in the compilation of this paper, several ways have been conducted using the correct method as well as the procedures for the preparation of writing in general. Data collection methods used were field studies to obtain income data of tourism activities in Puri Agung Kerambitan, interviews with managers and residents of Puri Agung Kerambitan to support the legitimacy of data obtained. Methods of documentation and observation with the help of camera and photography were also applied in this study.

The next step was analyzing the data. Data were analyzed by a quantitative approach using Input-Output Analysis. According to Heng and Low (1990), Input-Output Analysis is an excellent analytical tool for measuring the impact of tourism on a practical level. Input-Output Analysis captures the economic portrait of an area at a given time using the principle of general equilibrium. Because this research belongs to a study of cultural and tourism studies, this data analysis takes into account the principles of culture and social science. The data found in the field, are inserted into the Puri Agung Kerambitan income table concerning tourism activities as well as the expenditure tables of Puri Agung Kerambitan from the physical and non-physical side. From the data in the table, we can see the amount of income from tourism activities and amount of expenditure of Puri Agung Kerambitan for the management cost for giving the best treatment for the castle.

In the final stages was the presentation of the results of the analysis. The presentation of the results of this data analysis using quantitative methods of inferencing statistics. This method was used in the results of the data taken with the aim of concluding all populations. The data was drawn in the form of tables, income tables of Puri Agung Kerambitan regarding tourism activities and expenditure tables of Puri Agung Kerambitan from the physical and non-physical aspect. This data was described and given a descriptive explanation to answer the problem which is the basis of writing this research, alleviating the management cost of the Puri. This explanation is related to the income of the palace of any tourism activities in 2016 and the expenditure of the palace for any management costs that have been physically and non-physically divided by 2016 . The data presentation of descriptive analysis results was also used to answer the problem of income ability of these tourism activities in alleviating the maintenance cost of Puri Agung Kerambitan.

\section{RESULTS AND DISCUSSION}

In the four visits to Puri Agung Kerambitan which the researcher drafted in the proposal, three visits have been conducted on August 15, September 4 and September 18, 2017. The first visit on August 15, 2017, was a survey of research sites and permits and were welcomed by the palace residents as well as the palace tourism manager. On the second and third visit on September 4th and 18th September 2017, the researchers used to find data of expenditure and income of tourism in Puri Agung Kerambitan. The data obtained $y$ the technique of interviewing informants, palace managers and employees. It was difficult to get very accurate data with just two arrivals. Due to the changing in management structure and the absence of written data of daily / monthly expenditures of Puri Agung Kerambitan, the data of this research depends on the memories and experiences of the palace members that the researchers combine to get the results that the researcher feels quite appropriate and match with each data.

Puri Agung Kerambitan, Tabanan has three tourism packages. The first is Puri Day with the price of $\mathrm{Rp}$. 150,000 to Rp. 200,000 per person depending on the number of guests coming. In the activities of Puri Day, tourists can enjoy the original charm of Balinese Pendet dance as well as interact directly with Balinese dancers in Joged Bungbung. Interesting activities such as traditional Tejog game and tug of war, Balinese offerings making up to kites making can be followed by tourists. Lunch and tour around the castle became an interesting and anticipated part of this Puri Day package. Minimum order for this Puri Day activities is 20 people with the price of Rp. 200,000 per person. Lowest price Rp. 150,000 can be obtained if the tourists booked as many as 126 to 200 people maximum.

In addition to Puri Day, the package also offered is Puri Wedding. The package is divided into three categories: Puri Wedding Alit, Puri Wedding Madya and Puri Wedding Agung, tailored to the wishes and capabilities of each traveler's cost. Starting from the price of Rp. 10.000.000 nett, this package offers a traditional Balinese wedding procession experience with a touch of the castle. Starting from the bridal couple who is accompanied by the family of the castle with all the equipment of ceremony such as banten, spear and tedung; Mask dances and Pendet dance accompany the bride to the temple of the castle; from wedding procession of the bride until dinner will be accompanied by Jogged Bungbung dance enliven the choice of tourists in this Puri Wedding package. The difference of Puri Wedding Alit, the package of Puri Wedding Madya worth Rp. 12.000.000 and Puri Wedding Agung with a value of Rp 17.000.000 lies in the many types of dances that accompany the wedding ceremony process, the dance as part of entertainment while enjoying dinner, and the use of joli or bridal stretcher that is only obtained by ordering Puri Wedding Agung. This joli is proven to add tourists to enhance their package to Puri Wedding Agung. Not only tourists, the community around even outside the castle wanted to rent this joli several times for the benefit of their ceremonial procession. Surely the castle was not easy to grant permission, although the joli is indeed reserved for the show only.

If the procession of the ceremony felt too exhausting, but they still want to enjoy the atmosphere of the castle at night time complete with dance and dinner, Puri Agung Kerambitan has other options. Puri Night Dinner can be 
selected by tourists. The price is very low for the size of foreign tourists. With Rp. 270,000 to Rp. 400,000 per person, art attractions such as Okokan, Pendet dance, Mask dance until dinner can be enjoyed by tourists. Do not forget the Calonarang drama dance can be a show that will not be easily forgotten by tourists and will continue to remember even on their way home.

There are two tables that will show the results of this study. The first table is the income table of Puri Agung Kerambitan which starts from January 2016 to December 2016. In this table, the arrival date of the guests in detail is ignored and entered into one data in one month. As an example of January, there are two arrivals on January 12 and January 19 as many as 20 guests each. In the table, the two arrival dates are ignored and put together into the guest's arrival within a month of a total of 40 guests.

Similarly, in the months running and in the second table, the data table expenditure, researchers apply the same system. Due to the requirements of maximum pages on the article, the data shown in all tables is limited only on four months: January, March, September, and December. Meanwhile the total income and expenses on the bottom of the tables are shown as the actual amount from January until December 2016, to give the real and complete picture of the amount income and outcome from the tourism activities. The income from tourism activity table can be seen as below.

TABLE I

INCOME OF PURI AGUNG KERAMBITAN JANUARY 2016 - DECEMBER 2016 (EXAMPLES OF 4 MONTHS ONLY)

\begin{tabular}{clrr}
\hline \hline Month & \multicolumn{1}{c}{ Activity } & $\begin{array}{c}\text { Number } \\
\text { of Guests }\end{array}$ & \multicolumn{1}{c}{ Income } \\
\hline January & Puri Wedding & - & - \\
& Puri Day & 40 & $8,000,000$ \\
\multirow{5}{*}{ March } & Puri Dinner & - & - \\
& Puri Wedding & 2 & $2,000,000$ \\
& Puri Day & 140 & $28,000,000$ \\
September & Puri Dinner & 12 & $12,000,000$ \\
& Puri Wedding & - & - \\
& Puri Day & 385 & $77,000,000$ \\
December & Puri Dinner & - & - \\
& Puri Wedding & 1 & $1,500,000$ \\
& Puri Day & - & - \\
\multirow{2}{*}{ TOTAL Income January - December 2016 } & $234,875,000$
\end{tabular}

The results of research data are data of general spending Puri Agung Kerambitan. These data were divided into two categories: physical and non-physical aspects of expenses. Physical expenses, the division is the expenses for the maintenance of the palace, such as renovating and maintenance of Kori Agung, electricity bills and water bills, and the salaries of permanent and freelance employees, the center money combined with the mandatory fee of the castle members each month. This physical expenses also includes donations for two Tunini/grandmother who are still actively present at the castle of 5 Tunini who once existed in Puri Agung Kerambitan. Tuayah contribution was still part of the physical expenditure of this castle though Tuayah has long passed away. It became a permanent expenditure for the tourism castle since the tourism castle existed because of the services Tuayah/Late A.A. Ngurah Anom Mayun formed since the first time in 1980.

For the category of non-physical expenditure, divided into ceremonial expenditure. Expenses for daily ceremonies; weekly or monthly ceremonies such as full moon ceremony, Kajeng Kliwon, Tilem, Anggara Kasih; and big or annual ceremonies such as Nyepi, Galungan, and Kuningan. Provision of compensation funds like condolences or sickness, researchers also categorized as a form of non-physical cost. Here is the Physical Cost of Puri Agung Kerambitan from January-December 2016 as shown in table II and Non-Physical Cost of Puri Agung Kerambitan from January-December 2016 as shown in Table III:

TABLE II

PHYSICAL COST OF PURI AGUNG KERAMBITAN JANUARY 2016 - DECEMBER 2016 (EXAMPLES OF 4 MONTHS ONLY)

\begin{tabular}{|c|c|c|}
\hline Month & Physical & Cost \\
\hline \multirow[t]{11}{*}{ January } & $\begin{array}{l}\text { Perawatan bangunan - } \\
\text { renovasi Kori Agung }\end{array}$ & $2,000,000$ \\
\hline & Tagihan listrik & $2,500,000$ \\
\hline & Tagihan air & 180,000 \\
\hline & Gaji 4 pegawai tetap & $2,200,000$ \\
\hline & $\begin{array}{l}\text { Gaji } 5 \text { pegawai } \\
\text { freelance }\end{array}$ & 300,000 \\
\hline & Iuran tengah & 100,000 \\
\hline & Sumbangan untuk 2 & 100,000 \\
\hline & Tunini & \\
\hline & Iuran sampah & 200,000 \\
\hline & Tuayah (Duwe & 200,000 \\
\hline & Tengah) & \\
\hline \multirow[t]{10}{*}{ March } & Tagihan listrik & $2,500,000$ \\
\hline & Tagihan air & 180,000 \\
\hline & Gaji 4 pegawai tetap & $2,200,000$ \\
\hline & $\begin{array}{l}\text { Gaji } 5 \text { pegawai } \\
\text { freelance }\end{array}$ & 600,000 \\
\hline & Iuran tengah & 525,000 \\
\hline & Sumbangan untuk 2 & 525,000 \\
\hline & Tunini & \\
\hline & Iuran sampah & 400,000 \\
\hline & Tuayah (Duwe & $1,050,000$ \\
\hline & Tengah) & \\
\hline \multirow[t]{11}{*}{ September } & $\begin{array}{l}\text { Perawatan bangunan - } \\
\text { renovasi Kori Agung }\end{array}$ & $2,000,000$ \\
\hline & Tagihan listrik & $2,500,000$ \\
\hline & Tagihan air & 180,000 \\
\hline & Gaji 4 pegawai tetap & $2,200,000$ \\
\hline & $\begin{array}{l}\text { Gaji } 5 \text { pegawai } \\
\text { freelance }\end{array}$ & 750,000 \\
\hline & Iuran tengah & 962,500 \\
\hline & Sumbangan untuk 2 & 962,500 \\
\hline & Tunini & \\
\hline & Iuran sampah & 400,000 \\
\hline & Tuayah (Duwe & $1,925,000$ \\
\hline & Tengah) & \\
\hline \multirow[t]{4}{*}{ December } & Tagihan listrik & $2,500,000$ \\
\hline & Tagihan air & 180,000 \\
\hline & Gaji 4 pegawai tetap & $2,200,000$ \\
\hline & Iuran tengah & 18,750 \\
\hline
\end{tabular}


Sumbangan untuk 2

Tunini

Iuran sampah

18,750

Tuayah (Duwe

200,000

Tengah)

TOTAL Physical Cost January - December 2016

$81,513,000$

TABLE II

NON-PHYSICAL COST OF PURI AGUNG KERAMBITAN JANUARY 2016 - DECEMBER 2016 (EXAMPLES OF 4 MONTHS ONLY)

\begin{tabular}{|c|c|c|}
\hline Month & Physical & Cost \\
\hline \multirow[t]{2}{*}{ January } & $\begin{array}{l}\text { Daily ceremony - canang for } \\
30 \text { days }\end{array}$ & $3,000,000$ \\
\hline & $\begin{array}{l}\text { Weekly/monthly ceremony } \\
\text { Purnama, Kliwon, Tilem }\end{array}$ & $1,050,000$ \\
\hline \multirow[t]{6}{*}{ March } & $\begin{array}{l}\text { Daily ceremony - canang for } \\
30 \text { days }\end{array}$ & $3,000,000$ \\
\hline & Weekly/monthly ceremony & 450,000 \\
\hline & $\begin{array}{l}\text { Purnama, Kliwon, Tilem } \\
\text { Nyepi }\end{array}$ & $2,000,000$ \\
\hline & $\begin{array}{l}\text { Tunini sakit suka duka anggota } \\
\text { puri }\end{array}$ & 500,000 \\
\hline & $\begin{array}{l}\text { Sumbangan air mineral untuk } \\
\text { ogoh-ogoh }\end{array}$ & $1,000,000$ \\
\hline & Sumbangan ogoh-ogoh & $2,000,000$ \\
\hline \multirow[t]{4}{*}{ September } & Daily ceremony - canang for & \\
\hline & $\begin{array}{l}30 \text { days } \\
\text { Weekly/monthly ceremony }\end{array}$ & $2,000,000$ \\
\hline & Purnama, Kliwon, Tilem & $1,500,000$ \\
\hline & Galungan/Kuningan & $4,000,000$ \\
\hline \multirow[t]{4}{*}{ December } & Daily ceremony - canang for & \\
\hline & 30 days & $3,000,000$ \\
\hline & Weekly/monthly ceremony & \\
\hline & Purnama, Kliwon, Tilem & 600,000 \\
\hline
\end{tabular}

TOTAL Non-Physical Cost January December 2016

$62,850,000$

\section{CONCLUSION}

Good and successful data, by the title of this research, shows that this activity can ease the number of maintenance costs incurred by the castle everyday even up to the cost of great maintenance and management such as Galungan ceremony, renovating Kori Agung. From income data in one year as much as Rp.234.875.000 and expenses also in one year as much as Rp.144.363.000, Puri Agung Kerambitan get gross profit Rp.90.512.000. The amount is not small for the annual income, but it is less if we see it from the scale of tourism activities that can be taken by this palace.

By showing the data and the results of this research to the palace managers, it allows them to deeply analyze the tourism activities that have become the symbol of Puri Agung Kerambitan and the pride of local villagers. Further action in advance to develop the tourism in Puri Agung Kerambitan can be done, and the management of the palace's tourism can be addressed. With the development of generations in Puri Agung, the selection of actions and activities of tourism can certainly be more varied. This can be discussed at upcoming meetings between researchers and palace managers as well as on other research opportunities.

The results of research data are data of general spending Puri Agung Kerambitan. These data were divided into two categories: physical and non-physical aspects of expenses. Physical expenses, the division is the expenses for the maintenance of the palace, such as renovating and maintenance of Kori Agung, electricity bills and water bills, and the salaries of permanent and freelance employees, the center money combined with the mandatory fee of the castle members each month. This physical expenses also includes donations for two Tunini/grandmother who are still actively present at the castle of 5 Tunini who once existed in Puri Agung Kerambitan. Tuayah contribution was still part of the physical expenditure of this castle though Tuayah has long passed away. This became a permanent expenditure for the tourism castle since the tourism castle existed because of the services Tuayah/Late A.A. Ngurah Anom Mayun formed since the first time in 1980.

For the category of non-physical expenditure, divided into ceremonial expenditure. Expenses for daily ceremonies; weekly or monthly ceremonies such as full moon ceremony, Kajeng Kliwon, Tilem, Anggara Kasih; and big or annual ceremonies such as Nyepi, Galungan, and Kuningan. Provision of compensation funds like condolences or sickness, researchers also categorized as a form of non-physical expenditure.

Simply put, Puri Wisata's income data as in the following statistics:

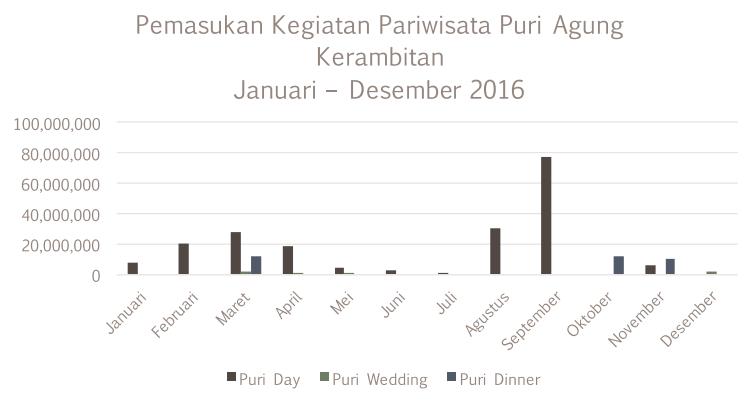

The outcome data as shown in this statistics:

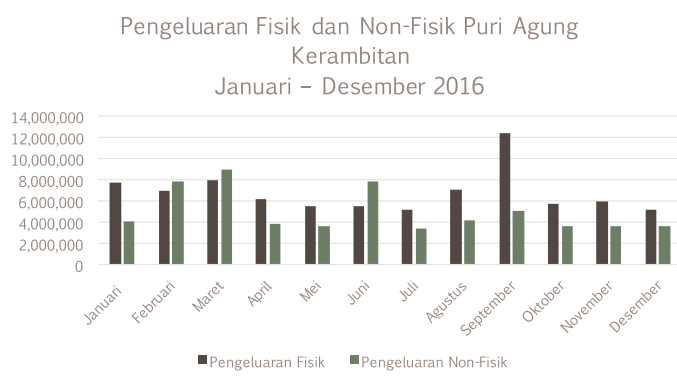

From the above data, it is clear that the income of Puri Wisata in one the year 2016 as much as Rp.234.875.000 with the highest income in September of Rp.77.000.000 
from Puri Day activities. Expenditure of Puri Wisata during the same period as much as Rp.144.363.000 with the highest expenditure also in September amounted to Rp.20.430.000 at an annual/large ceremony, because in this month Hindu celebrate Hari Raya Galungan and Kuningan which of course require cost much more to the size of the castle. From the difference between the income and expenditure of Puri Wisata, we can see the profit income of Rp.90.512.000 in 2016.

\section{ACKNOWLEDGMENT}

Highest appreciation to the Udayana University, which has funded this research through PNBP Dosen Muda Udayana University. High gratitude also goes towards Puri Agung Kerambitan on their endorsement for the data completion of this research.

\section{REFERENCES}

[1] Ardana. 2013. Pengaruh Perkembangan Pariwisata terhadap Struktur Perekonomian dan Kesejahteraan Masyarakat Bali. Pada: https://ardana45.wordpress.com/2013/05/15/pengaruhperkembangan-pariwisata-terhadap-struktur-perekonomian-dankesejahteraan-masyarakat-bali/

[2] Barke, Chris. 2014. Kamus Kajian Budaya. Yogyakarta: PT Kanisius.

[3] Denman, Richard. 2001. Guidelines for community-based ecotourism development. UK: WWF International.

[4] Heine-Geldern, R. 1982. Konsepsi tentang Negara dan Kedudukan Raja di Asia Tenggara. Jakarta: CV Rajawali.

[5] Heng, T.M. and Low, L. 1990. Economic Impact of Tourism in Singapore. Annals of Tourism Research, 17, 246-269. Management.

[6] Pemerintah Daerah Tingkat II Tabanan. 1998. "Monografi Desa Baturiti Kecamatan Kerambitan Kabupaten Daerah Tingkat II Tabanan,".

[7] Pendit, I Nyoman, S. 1994. Ilmu Pariwisata, Sebuah Pengantar Perdana - Cetakan Keenam (Edisi Revisi). Jakarta: PT Pradnya Paramita.

[8] Putra, I Nyoman Darma (ed.). 2015. Pariwisata Berbasis Masyarakat Model Bali. Denpasar: Buku Arti.

[9] Soethama, Gde Aryantha. 2011. Jangan Mati di Bali. Jakarta: Kompas.

[10] Spillane, James. 1985. Ekonomi Pariwisata, Sejarah dan Prospeknya. Yogyakarta: Kanisius.

[11] Sueca, N.P. 2007. "Peranan Puri dalam Dinamika Kebudayaan Bali pada Era Modernisasi," Fakultas Teknik Universitas Udayana.

[12] Suryadiarta, I Ketut dan I Made Sarjana. 2012. "Implementasi Ekonomi Hijau di Bidang Pariwisata: Kasus di Yayasan Karang Lestari, Desa Pemuteran, Gerokgak, Buleleng, Bali," Kerjasama Puslitbang Kebijakan Pariwisata Badan Pengembangan Sumberdaya Pariwisata dan Ekonomi Kreatif Kemenparekraf RI dan PS Agribisnis FP UNUD.

[13] The Mountain Institute. 2000. Community-Based Tourism for Conservation and Development: A Resource Kit.

[14] Wiktionary website. $2016 . \quad$ On: https://id.wiktionary.org/wiki/wisata_puri

[15] Yuliantini, Wayan. 2016. Perkembangan Pariwisata di Bali. Pada: http://www.academia.edu/16006954/Perkembangan_Pariwisata_di_B ali 